\author{
dr Mateusz MACHAJ \\ Instytut Nauk Ekonomicznych, Uniwersytet Wrocławski \\ e-mail: mateusz.machaj@uwr.edu.pl
}

DOI: $10.15290 /$ ose.2017.02.86.03

\title{
SPADAJĄCY UDZIAŁ PLAC W PKB W TRZECIEJ RP A EKONOMICZNA SYTUACJA SILY ROBOCZEJ
}

\begin{abstract}
Streszczenie
Przez potransformacyjny okres udział płac w PKB w Polsce systematycznie spadał. W spłyconym rozumieniu, udział płac w PKB odzwierciedla pogarszającą się sytuację ekonomiczna siły roboczej zarówno w kwestii poziomu życia, jak i nierówności dochodowych. Celem artykułu jest wskazanie na to, że spadający udział płac nie oznacza pogarszającej się sytuacji pracy, gdyż jako wskaźnik jest wypadkową wielu rozmaitych czynników. Co więcej, Polska specjalnie nie wyróżnia się na tle innych krajów ani wysoko rozwiniętych, ani tych po transformacji, w których udział płac również spada. Niezależnie od tego, w Polsce płace dynamicznie rosna, a w ostatnich latach nawet szybciej od produktywności, zaś wskaźniki nierówności dochodowych utrzymują się na stałym lub nawet malejącym poziomie. Należy zatem uznać, że spadający udział płac może iść w parze z poprawą sytuacji ekonomicznej siły roboczej.
\end{abstract}

Słowa kluczowe: udział płac w PKB, przemysł, kapitał, III Rzeczpospolita Polska

\section{FALLING WAGE SHARE IN GDP IN MODERN POLAND AND ECONOMIC SITUATION OF LABOUR FORCE}

\section{Summary}

During the Polish transformation, the wage share was systematically falling. In simplified terms, a falling wage share illustrates a worsening situation of the labour force with regard to living conditions and income inequality. The aim of the paper is to demonstrate that this is not necessarily the case, since a wage share results from various factors. What is more, in this respect Poland does not differ from other countries, both developed and transforming, where the wage share is also decreasing. On the other hand, Polish wages are dynamically increasing, in the recent years even faster than productivity, while the income inequality index is stable, or even declining. It can be, therefore, concluded that the falling wage share goes together with better conditions for the labour force.

Key words: wage share in GDP, industry, capital, Poland

JEL: E24, J3, P20 


\section{Wstęp}

W Polsce transformacyjnej i potransformacyjnej charakterystycznym zjawiskiem jest zmniejszający się udział płac w PKB. Często w ekonomicznej publicystyce używa się tej statystyki jako argumentu na opisywanie dwóch negatywnych zjawisk. Po pierwsze, chodzi o rzekomo pogarszające się warunki siły roboczej w Polsce. Założenie jest takie, że skoro relatywny udział w PKB staje się coraz mniejszy, to odbywa się to kosztem warunków bytowych. Po drugie, ma to stanowić wskazanie na zwiększającą się rozpiętość dochodową w Polsce. Z kolei, ten argument jest inspirowany opracowaniami Thomasa Pikiettiego, który sugerował w swojej słynnej książce, że relatywna, ekonomiczna pozycja kapitału ulega poprawie kosztem pracy.

Jak wskazano w niniejszym artykule, zmniejszający się udział płac nie musi iść w parze z pogarszającymi się warunkami życia. Spadek udziału może wiązać się z dynamicznym wzrostem gospodarczym i systematycznie poprawiającą się sytuacją ekonomiczną siły roboczej. Ponadto, spadający udział płac może jednocześnie współwystępować wraz ze spadkiem nierówności dochodowych.

\section{Kwestie metodologiczne}

Gdy mowa o udziale płac w PKB, to warto pamiętać o tym, że istnieją różne metody jego pomiaru, które niejednokrotnie moga prowadzić do znaczacych rozbieżności interpretacyjnych. Przede wszystkim produkt krajowy brutto może być wyrażony w cenach czynników produkcji albo w cenach rynkowych. W przypadku wyrażenia go w cenach rynkowych mamy trzy części składowe, tj.: płace, operacyjną nadwyżkę brutto oraz podatki pośrednie. W związku z tym, warto pamiętać, że jeśli udział płac wynosi na przykład $40 \%$ w PKB w cenach rynkowych, to nie oznacza, że czyste dochody z kapitału stanowia pozostałe $60 \%$. Najpierw należałoby odjąć podatki pośrednie, a więc wyliczyć produkt krajowy brutto w cenach czynników produkcji. Wtedy pozostaja dwie części składowe, takie jak: płace i operacyjna nadwyżka brutto.

Jednakże, nawet wówczas, pełna ścisłość nie zostaje osiagnięta, ponieważ operacyjna nadwyżka brutto nie jest terminem określającym czysty dochód z kapitału. W operacyjnej nadwyżce zawiera się także dochód mieszany, a więc osiagany w wyniku prowadzenia jednoosobowej działalności gospodarczej. Trudno jest jednoznacznie określić, jaką kategorią dochodową są mali przedsiębiorcy, realizujący samozatrudnienie [Mihnenokaa, Senfeldea, 2015, s. 1037]. Czy ich dochody należy zaliczyć do dochodu z kapitału, czy z pracy? Badania statystyczne nie dają konkretnej odpowiedzi na to pytanie (chociaż teoria ekonomii raczej sprzyjałaby tezie, że są to dochody z kapitału, gdyż zarobek nie jest wypłacany przed sprzedaża produktu, tak jak w tradycyjnym systemie zatrudniania siły roboczej). Stosuje się rozmaite metody. Niektórzy sugeruja, żeby całość zarobku uznawać za zarobek na kapitale, a inni na pracy. Często jest również stosowana opcja trzecia: rozdział dochodu mieszanego w proporcji analogicznej do pracy 
i pozostałości operacyjnej nadwyżki [Trapp, 2015, s. 2-4]. Z tych powodów cała empiryczna analiza „funkcjonalnej dystrybucji” między czynnikami produkcji jest bardzo problematyczna [Guerriero, Sen, 2012, s. 20].

Abstrahując od tych problemów, jednocześnie warto pamiętać o dwóch dodatkowych, istotnych kwestiach. Po pierwsze, operacyjna nadwyżka brutto, nawet po odjęciu dochodu mieszanego, pozostaje brutto, a więc nie uwzględnia amortyzacji kapitału. Wobec tego, nie jest to dochód czysty, faktycznie wskazujący na zarobki kapitałowe. Po drugie, należy zauważyć, że w udziale płac bierze się pod uwagę płace i wszelkie kompensacje pracowników. Zatem także jest to kwota brutto, która trochę zawyża rzeczywisty udział w produkcie, gdyż uwzględnia składki na ubezpieczenia społeczne i podatki płacone przez pracownika [Schneider, 2011, s. 2]. Jednak nie zmienia to faktu, że podatki płacowe przede wszystkim zmniejszaja płace netto.

\section{Udział płac w Polsce na tle innych krajów po transformacji}

Na poniższym wykresie przedstawiono dynamikę udziału płac w PKB (w cenach czynników produkcji), w krajach okresu transformacji.

RYSUNEK 1.

\section{Udział płac w PKB, w krajach po transformacji (rocznie)}

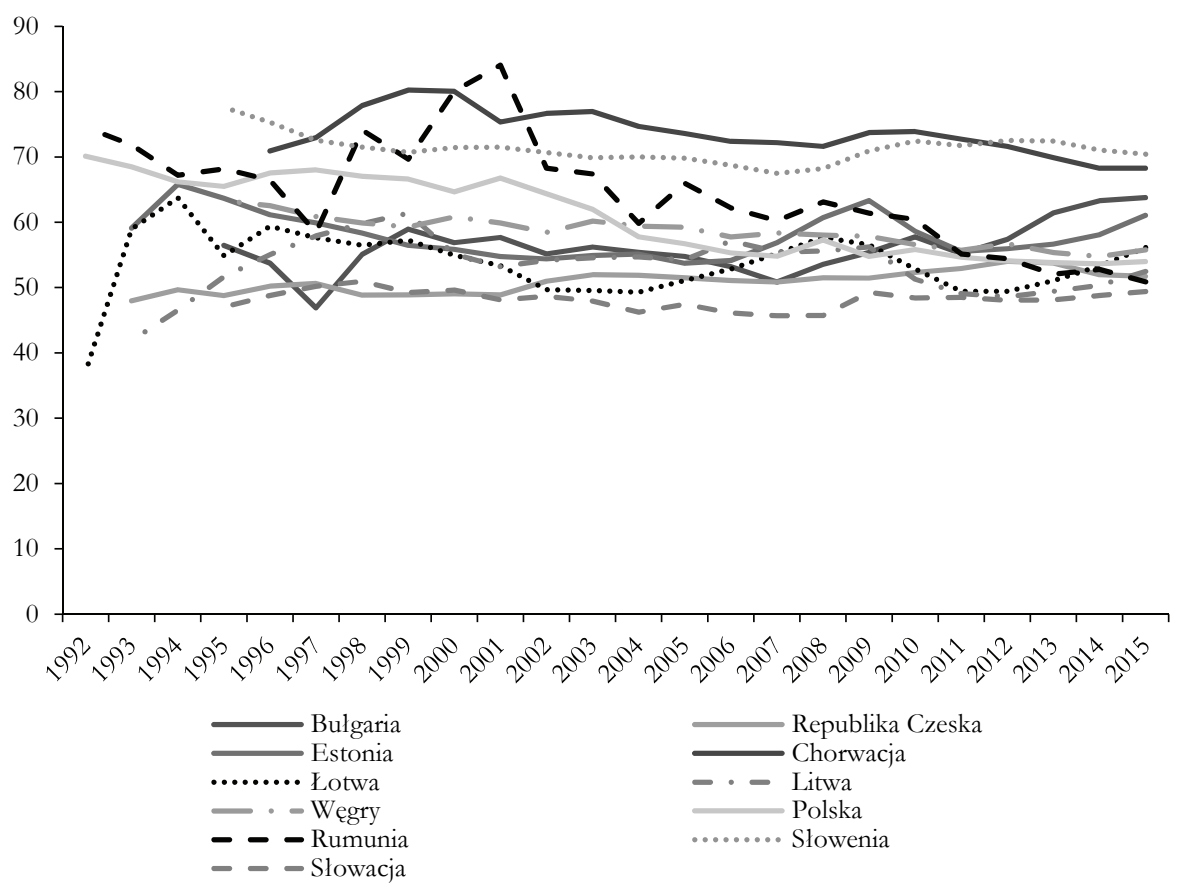

Źródło: dane Eurostat. 
W każdym z krajów dynamika wyglądała bardzo różnie i w zasadzie wymagałaby dokładniejszego omówienia. Jednakże najistotniejszy pozostaje ogólny trend wspólny dla wszystkich krajów, niezależnie od dynamiki i poziomu startowego, a mianowicie: generalnie udział płac w PKB długookresowo zmniejsza się. Samo zmniejszanie się tego wskaźnika nie musi w istocie nic mówić o tym, czy sytuacja gospodarcza w danym kraju się poprawia. Nie musi także nic mówić o poziomie życia najbiedniejszych pracowników.

Celem selekcji, autor porównał Polskę z Republiką Czeska, która jest często stawiana za transformacyjny wzór (Czechy to najbogatszy postkomunistyczny kraj, jeśli chodzi o poziom PKB per capita).

RYSUNEK 2.

Udział płac w PKB, w Polsce i Czechach po transformacji

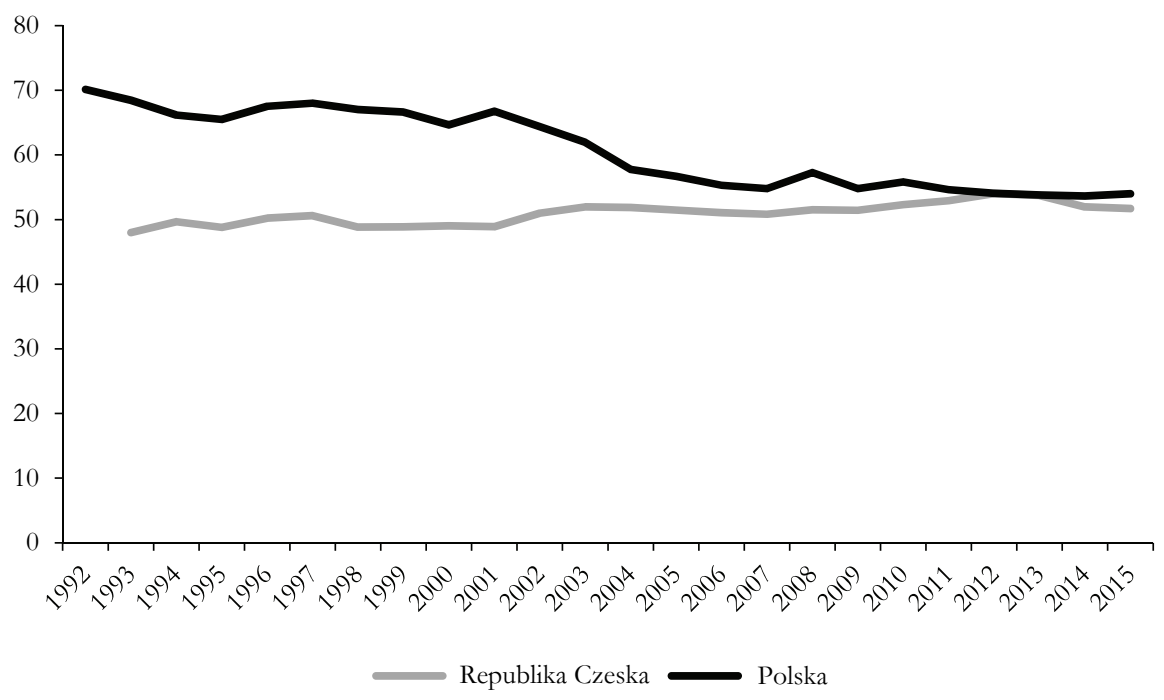

Źródło: dane Eurostat.

Gdyby rzeczywiście udział płac w PKB miarodajnie oddawał poziom życia w danym kraju, to prowadziłoby do wniosku, że w Czechach od lat żyje się gorzej niż w Polsce. Tymczasem w rzeczywistości udział płac należy traktować analogicznie do uśrednionej agregatowej ceny, podobnej w swojej naturze do wskaźnika cen detalicznych. W przypadku wskaźnika cen detalicznych mogą działać różne siły go zwiększające bądź zmniejszające. Niektóre z nich mogą być pozytywne, a inne negatywne. Przykładowo w Polsce, w 2015 roku doszło do zjawiska deflacji cenowej. Wynikała ona ze zmian po stronie podażowej i wzrostu produktywności (również za sprawą dostępu do tanich surowców). Przedstawiane interpretacje nie były, rzecz jasna, jednolite, ale z pewnością nie dominowały opinie negatywne. Zdarzały się na tyle pozytywne interpretacje, że nawet Rada Polityki Pieniężnej de facto (choć nie de iure) zrezygnowała z realizacji założonego celu inflacyjnego (2,5 procenta z odchyleniem jednoprocentowym). Jednak można sobie 
wyobrazić zjawisko deflacji, wynikającej z negatywnych zmian w gospodarce: na przykład poważnego makroekonomicznego kryzysu bankowego, który skończyłby się likwidacją znacznej części masy depozytowej. Oba te zjawiska powodowałyby ten sam efekt: deflację cenową, lecz nie można byłoby uogólniać, że deflacja cenowa to zawsze oznaka czegoś złego.

Dokładnie tak samo należy postrzegać zjawisko spadającego udziału płac w PKB. Udziały w PKB są następstwem wyceny rynkowej czynników produkcji. Jeśli jakieś czynniki produkcji zaczynają być wyżej wartościowane na rynku i drożej zakupywane, to objawia się to w generowaniu wyższej ekonomicznej wartości, co w konsekwencji prowadzi do rosnącego udziału w produkcji.

\section{Przykładowe, historyczne przypadki zmian udziału płac w PKB}

Zmiana udziału płac w każdym z kierunków może charakteryzować pozytywne lub negatywne zjawiska gospodarcze. W artykule wymieniono kilka przykładów.

$\mathrm{Na}$ początku lat dziewięćdziesiątych w gospodarkach transformacyjnych znacznie zwiększyła się swoboda działalności gospodarczej (a może w zasadzie: pojawiła się). Poskutkowało to powstaniem wielu nowych firm na rynku, zajmujących się produktywną działalnością (m.in. był to efekt ustawy Wilczka). W efekcie doszło do ukształtowania nowego źródła wartości ekonomicznej - która oczywiście miała swój procentowy wkład w ostateczna produkcję. Sektor prywatny zaczął generować coraz to większą produkcję krajową za którą odpowiadali prowadzący działalność gospodarczą. Spadek udziału płac w PKB jest w takim przypadku wyrazem czegoś pozytywnego: udział spada nie dlatego, że płace spadają ale dlatego, że pojawia się nowe źródło ekonomicznej wartości. Udział płac w PKB w Polsce na przełomie lat 1992-2003 spadł o dziesięć procent, ale nie dlatego, że spadły płace, lecz dlatego, że na wzrost PKB w większym stopniu miały wpływ pozapracowe czynniki produkcji. Nota bene analogicznie może być $z$ napływem kapitału zagranicznego, który oferuje wyższe płace niż kapitał lokalny [zob. np. dane dla Polski: Raport płacony..., 2015]. Mimo że zwiększa płace, to jednocześnie może zmniejszać ich udział w PKB. Udział to wielkość relatywna. Jego zmniejszanie nie oznacza absolutnego spadku.

W gospodarce amerykańskiej, w okresie industrializacji udział płac w PKB prawdopodobnie zwiększał się. Autor użył określenia prawdopodobnie, gdyż trudno mówić o jakichś sensownych statystykach $z$ tego okresu' ${ }^{1}$ Pomiary produkcji na dobre zaczęły się dopiero po drugiej wojnie światowej (choć Simon Kuznets podejmował wcześniejsze próby jeszcze w latach trzydziestych XX wieku). Z estymacji, które są znane, jednak wynika, że w tym czasie podnosił się udział płac. Szacunki wahały się między 12 a 6 punktami procentowymi [Budd, 1960, s. 399]. Można to tłumaczyć konkurencyjna presją o pracowników migrujących do ośrodków miejskich za wyższym zarobkiem niż ten oferowany na terenach rolnych. Generalnie, taki wzrost udziału płac charakteryzowałby się tendencja pozytywną, charakterystyczną dla industrializacji. 1989].

${ }^{1}$ Dobrym przykładem takich ograniczeń mogą być opracowania Christiny Romer. Zob. np. [Romer, 
Z kolei, wielki kryzys gospodarczy w USA dostarcza przewrotnego przykładu. W trakcie lat trzydziestych udział płac w PKB rósł [The Labour Share..., 2015, s. 15]. Jest to zjawisko naturalne, gdy uwzględni się fakt, że dochodziło do masowych bankructw. Pierwsza rzecz, w którą najmocniej uderzył kryzys, to wszelkie obroty finansowe i kapitałowe. Pracownicy oczywiście także odczuwali zwolnienia i rekordowy wzrost bezrobocia, a na ich płace pojawiła się presja spadkowa. Mimo to, było to tempo mniejsze niż dotyczące operacyjnej nadwyżki brutto. Z tego względu udział płac w tym czasie w PKB rósł, ale mało kto potraktowałby ten przypadek jako coś pozytywnego (w zasadzie lokalne szczyty trendu udziału płac w PKB w USA przypadają na okresy recesji). Podobnie byłoby, gdyby na przykład w Polsce doszło do kryzysu walutowego, który poskutkowałby ogromnym odpływem kapitału za granicę. Prawdopodobnie udział płac w PKB zwiększyłby się. Jednak trudno byłoby to traktować jako objaw zdrowej, ekonomicznej przemiany. Choć taka sytuacja nie miała miejsca, to ów gedanken experiment ilustruje w tym przypadku, że wielkość indeksu nie jest jednoznaczna bez dodatkowych informacji.

Wracając do głównej historii rozwiniętych gospodarek, po drugiej wojnie światowej udział płac w PKB utrzymywał się na stałym poziomie (lub odrobinę rósł) do późnych lat siedemdziesiątych. Przypuszczalnie główna przyczyna ponownie tkwiła w mobilizacji na rynku pracy i wejściu na rynek nowego pokolenia, również pokolenia kobiet, lepiej wykształconego od poprzedników. Można określić ten etap jako eksplozję „,kapitału ludzkiego", który miał większe znaczenie w procesach produkcji. Działania te stopniowo wygasały pod koniec lat siedemdziesiatych, gdy tendencja we wszystkich rozwiniętych krajach odwróciła się [Schneider, 2011, s. 3-4]. Udział płac zaczął spadać aż do dzisiaj (z pewnymi, ewentualnymi przerwami). W dużej mierze można to przypisać wygaśnięciu efektu kapitału ludzkiego oraz stale rosnącej roli mechanizacji i dóbr kapitałowych. Nie bez wpływu pozostaje fakt, że od lat siedemdziesiątych znacznie wzrosła rola sektorów: finansowego, bankowego, ubezpieczeniowego i biznesowego, w których wartość dodana po stronie pracy była relatywnie niższa, mimo konieczności zatrudniania wyspecjalizowanych pracowników [Serres i in. 2001, s. 394]. Tymczasem jedno i drugie zjawisko można potraktować pozytywnie: zarówno wzrost udziału płac po drugiej wojnie, jak i spadek udziału płac od lat siedemdziesiatych to w zasadzie pozytywne, ekonomiczne zjawiska: gdzieś jest generowana nowa i wyższa wartość ekonomiczna. Generowanie nowej wartości nie oznacza, że czemuś jest odbierana poprzednia wartość. Choć oczywiście sporne pozostają same zjawiska finansjonalizacji i wzrostu roli kreacji pieniądza, które wynikają ze wzmocnienia państwowych monopoli menniczych w latach siedemdziesiątych.

Celem powyższych przykładów nie jest usystematyzowanie trendu udziału płac czy też poszukiwanie uniwersalnych prawideł dla wszystkich krajów na różnych etapach rozwoju. Powyższe przykłady mają charakter niemalże imponderabiliów. Mają one służyć ledwie jako pewne demonstracje tego, że wskaźnik sam w sobie nie przesądza o pozytywnych bądź negatywnych zmianach. Wymaga się jeszcze omówienia czynników towarzyszących. Najważniejsze w tym przypadku jest wyjście od wielkości ogólnej krajowej produkcji i tendencji w samych poziomach płac realnych - niekoniecznie 
jako udziału w odniesieniu do samego PKB. Więcej o sytuacji siły roboczej bezpośrednio informuje bowiem poziom realnych dochodów, a nie procentów wobec innego indeksu.

\section{Udział płac w krajach po transformacji}

Skoro udział płac można traktować w pewnym sensie jako agregatowy, makroekonomiczny wskaźnik cenowy, to jego tendencje należy również oceniać w kategoriach różnych czynników, które na niego wpływaja. Praktycznie, wszystkie rozwijające się kraje po transformacji są poddawane dwom powszechnym tendencjom, te natomiast ostatecznie oddziałują na poziom udziałów płac.

Pierwszą z nich jest znane zjawisko konwergencji po stronie pracy, czyli nadganiania średnich krajów za bogatymi. Wiąże się z tym wyższe tempo wzrostu gospodarczego i przede wszystkim wyższe tempo przyrostu płac, aniżeli w najbogatszych gospodarkach OECD. Oczywiście, konwergencja obejmuje tylko kraje po transformacji, które faktycznie rozwijają się. Pierwotne czynniki produkcji w krajach nadganiających kryją w sobie potencjalne produkcyjne możliwości, a to oznacza, że kapitał napływający do kraju będzie relatywnie bardziej podbijał ich ceny niż w krajach już bogatych. $Z$ tego względu można zaobserwować np. w krajach Europy Środkowo-Wschodniej zauważalnie wyższą dynamikę płac realnych, aniżeli w krajach najbogatszych. Ta konwergentna tendencja przyczynia się do presji na wzrost udziału płac w PKB w kierunku osiagania poziomów krajów najbardziej zamożnych.

Druga tendencja natomiast łączy się z naśladowaniem zmian w krajach po transformacji, które zaszły i zachodzą w krajach bogatych. Naturalnie, rzecz dotyczy rozwoju: sektora dóbr kapitałowych, spółek technologicznych oraz wszelkich produktywnościowych udogodnień, które są przypisane nie kapitałowi ludzkiemu i czynnikowi pracy, lecz pozostałym czynnikom produkcji (choć sama klasyfikacja zmian technologicznych może być problematyczna). Te przemiany biora górę w krajach potransformacyjnych nad tendencjami związanymi z konwergencja. W zasadzie tendencje spadkowe są dosyć podobne [Rincon-Aznar i in. 2015, s. 60]. Przypisując je poszczególnym ze zmiennych, można zauważyć ogromne podobieństwo między krajami rozwijającymi się a bogatymi [Stockhammer, 2013, s. 32-33].

Z czego może wynikać owa przewaga? Najwyraźniej nowa ekonomiczna wartość jest bardziej generowana przez czynniki pozapracowe, aniżeli przez czynniki związane z praca. Warto w tym miejscu podkreślić, że chodzi o generowanie jej w większym stopniu. Nie należy przecież zapominać o podstawowym fakcie matematycznym: jeśli udział płac w PKB maleje, to nie znaczy, że udział pracy w przyroście PKB jest ujemny. Oznacza to tylko tyle, że pozostałe czynniki, decydujące o wzroście, przyrastaja w tempie szybszym niż praca. Tymczasem zarówno praca, jak i czynniki kapitałowe powodują wzrost gospodarczy².

2 Nota bene badania rynku pracy, przeprowadzone przez Narodowy Bank Polski, wskazują, że w Polsce płace długookresowo podążaja za wydajnościa pracy. Przykładowo, w latach 2009-2012 wydajność pracy rosła znacznie szybciej niż płace realne, natomiast w latach 2012-2016 płace rosły znacznie szybciej niż 
Przykładowo wystarczy, że w danym roku kalendarzowym za wzrost PKB w 60 procentach odpowiada np. transfer technologii z zagranicy, a za pozostałe 40 procent wzrost produktywności po stronie pracy. Wtedy jedna i druga grupa czynników produkcji doświadczaja przyrostu w realnym wynagrodzeniu, ale praca w mniejszej mierze, co również wyraża się w pogarszającym udziale w PKB. Jednak nie dowodzi to słuszności marksistowskiej logiki na temat tego, że jakiś czynnik produkcji „wyrwał” innemu dotychczasowe części zarobków. Wiąże się z tym to, że obydwa czynniki mają lepszą sytuację, ale jeden z nich przyrósł bardziej od drugiego.

Z tych przyczyn samo uwzględnienie udziału płac w kontekście dobrobytu jest niedostateczne. Należy przy tym rozważać inne aspekty, takie jak: zmiana kompozycji pozostałych czynników, płace realne, wskaźnik zatrudnienia czy bezrobocia.

\section{Udział płac a dystrybucja dochodu}

Na koniec warto zwrócić uwagę na kwestię związaną z podziałem dochodu oraz malejącym udziałem płac. Thomas Piketty rozprawiając o dyskursie nad kwestią kapitału i pracy, wprowadził sugestię, jakoby źródeł powiększających się różnic dochodowych było można dopatrywać się w rzekomej dychotomii między pracą a kapitałem [Piketty, 2015a]. W rozmaitej formie takie argumenty moga pojawiać się nie tylko w dyskursie publicystycznym, lecz także w opracowaniach naukowych. Przykładem tego może być analiza wskazująca na korelację rosnącego udziału płac w PKB i zmniejszających się nierówności dochodowych [Daude, Garcia-Peñalosa, 2007, s. 825].

$\mathrm{Z}$ pewnością dane dotyczące polskiej gospodarki tego nie potwierdzają. W Polsce od lat lekko spada udział płac w PKB, a jednocześnie wskáninik Giniego wykazuje drobną i stabilną tendencję spadkową. Tę sytuację prezentuje rysunek 3 .

Wiąże się to z tym, że przy jednoczesnym spadku udziału płac w PKB następuje zmniejszenie nierówności majątkowych w społeczeństwie. Zjawisko to można także wytłumaczyć w analogiczny do powyższego sposób: to, że jeden czynnik agregatowo ma mniejszy udział w produkcie nie oznacza z konieczności, iż pogłębia się zróżnicowanie (tak jak nie oznacza, że musi pogarszać się jego sytuacja). Nierówności dochodowe wszakże dotyczą: nierówności dochodowych, a nie nierówności dochodowych między czynnikami produkcji. Zróżnicowanie dochodowe może być następstwem różnic wewnątrz danego czynnika produkcji. Po serii krytycznych opinii skierowanych wobec Pikettiego, ten przyznał, iż różnice dochodowe, które analizuje, wcale nie muszą wynikać immanentnie z jego oryginalnych (i wattpliwych) teorii kapitałowych [Piketty, 2015b]. Moga ledwie wynikać $z$ tego, że wewnątrz siły roboczej istnieje bogatsza klasa menedżerów, której zarobki rosną zdecydowanie szybciej niż pracowników niższego szczebla. Temu zwiększającemu się zróżnicowaniu nie musi towarzyszyć pogarszający się udział płac w PKB (może nawet rosnaćc).

wydajność pracy. Długookresowo jest dostrzegalna zbieżność wydajności i płac. Zob.: [Kwartalny raport o rynku pracy..., 2016, s. 17]. 
RYSUNEK 3.

\section{Współczynnik Giniego w Polsce a udział płac w PKB}

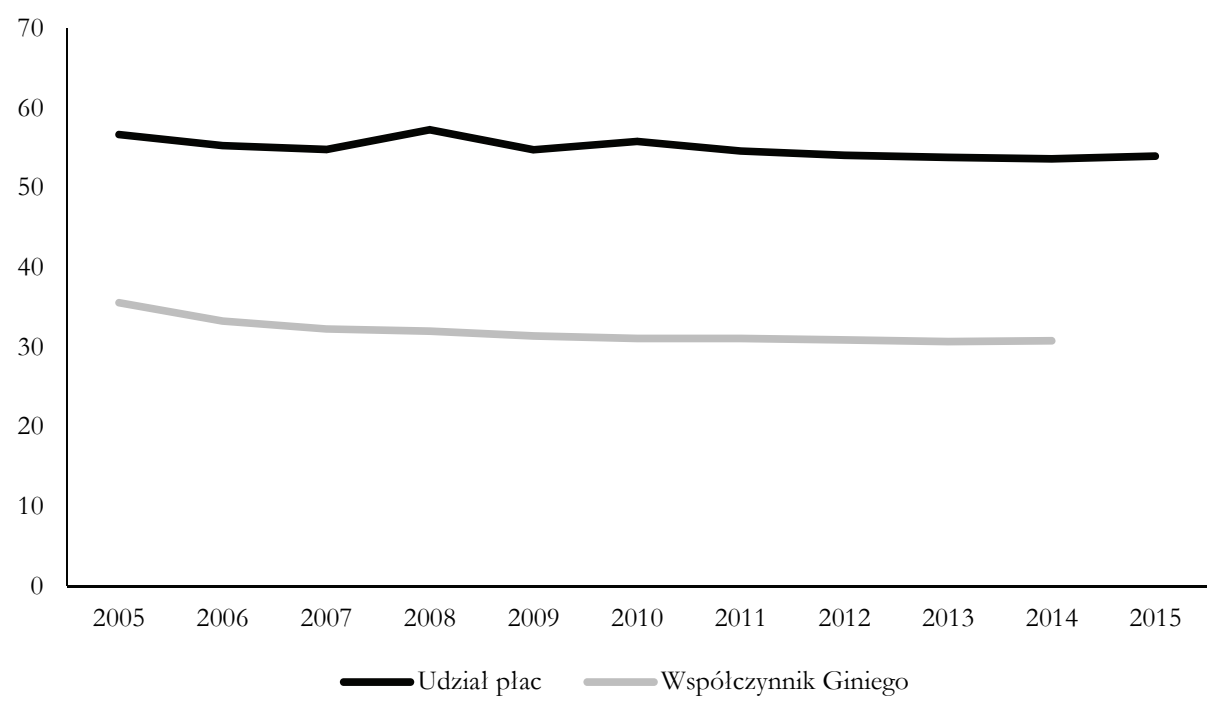

Źródło: dane Eurostat.

Analogicznie, nie ma takiej zależności w przypadku polskiej gospodarki, co jednoznacznie potwierdzają dane. Źródła osiagania zarobków w Polsce zmieniają się relatywnie na korzyść pozapracowa. Ekonomiczna wartość, dochody i wzrost gospodarczy w większym stopniu są generowane czynnikami innymi niż siłą roboczą. Mimo względnie większego udziału przypadającego na umownie zwany „kapitał”, różnice majątkowe w Polsce minimalnie zmniejszyły się.

\section{Podsumowanie}

Bez wątpienia, od lat udział płac w Polsce w PKB zmniejsza się. Jak starał się wykazać autor tego artykułu, nie oznacza to jednak zjawiska immanentnie negatywnego. Hipoteza o tym, że spadający udział płac w PKB jest niekorzystny dla siły roboczej, przypisuje temu wskaźnikowi więcej niż on wyraża. Jeśli poziomy płac podniosą się o kilkadziesiąt procent, ale mniej niż pozostałe udziały w PKB, to sam udział płac zmaleje (tak jak zresztą działo się to w większości krajów na świecie). Nie przyczynia się to do pogorszenia sytuacji siły roboczej. Przeciwnie, w wyniku implementacji nowych rozwiązań produkcyjnych pozwala to na dodatkowy, znaczący wzrost płac realnych, który jest następstwem wzrostu produkcji i produktywności pozostałych czynników produkcji (w stopniu większym niż przy pracy). 
Rosnący, podobnie jak spadający, udział płac może być rezultatem zarówno negatywnych, jak i pozytywnych tendencji zachodzących w gospodarce. Przykładowo, jeśli zwiększa się „,kapitał ludzki” w gospodarce bardziej niż w przypadku pozostałych czynników, to można dostrzec tego pozytywne efekty współwystępujące ze wzrostem udziału płac. Jednakże wzrost ten nie jest sam w sobie dobry tylko dlatego, że jest wzrostem, lecz dlatego, iż praca staje się bardziej produktywna. Sam udział płac może także wzrosnać, jeżeli na przykład masowo zaczną bankrutować firmy prowadzące jednoosobowa działalność, choć trudno byłoby to określić jako rzecz zdecydowanie pozytywna (lecz wtedy warto by przeanalizować przyczyny takich bankructw).

Analogicznie, udział płac w PKB może spadać, gdy zwiększa się liczba firm prowadzących działalność gospodarcza. Takie zjawisko zachodziło podczas procesów transformacyjnych, ponieważ przedsiębiorczy sektor prywatny stawał się głównym źródłem wzrostu gospodarczego, to spadający udział płac w PKB był czymś w zupełności naturalnym. Tendencja ta została wzmocniona w wyniku napływu produktywnego kapitału zagranicznego.

Można zatem wnioskować, że zdrowa i rozwijająca się gospodarka może współwystępować wraz z malejącym udziałem płac w PKB. Sam spadający udział nie jest zjawiskiem negatywnym per se.

\section{Literatura}

Budd E. C., 1960, Factor Shares, 1850-1910 Trends in the American Economy in the Nineteenth Century, Princeton University Press, http://www.nber.org/chapters/c2484.pdf (data wejścia: 10.08.2016).

Daude E., Garcia-Peñalosa C., 2007, The Personal and the Factor Distributions of Income in a Cross-Section of Countries, "Journal of Development Studies", vol. 43, no. 5.

Duenhaup, P., 2011, The Impact of Financialization on Income Distribution in the US A and Germany: A Proposal for a New Adjusted Wage Share, Macroeconomic Policy Institute, Working Paper, no. 7, http://www.boeckler.de/pdf/p_imk_wp_7_2011.pdf (data wejścia: 10.08.2016).

Guerriero M., Sen K., 2012, What Determines the Share of Labour in National Income? A Cross-Country Analysis, IZA DP, no. 6643, Working Paper, http://ftp.iza.org/ dp6643.pdf (data wejścia: 10.08.2016).

Koncepcja Przestrzennego Zagospodarowania Kraju, 2011, M. Kowalski (red.), Wydawnictwo CeDeWu, Warszawa.

Kowalski J., 2005, Instytucjonalna analiza transformacji ustrojowej. Od planu do rynku, [w:] Nowa ekonomia, S. Piotrowski (red.), Wydawnictwo Naukowe PWN, Sopot.

Kwartalny raport o rynku pracy w III kw. 2016, 2016, Narodowy Bank Polski, Warszawa.

Mihnenokaa A., Senfeldea M., 2015, Wage share as a factor of income inequality in the context of the structure of national economy, "Procedia Economics and Finance", no. 26.

Piketty T., 2015a, Kapitał w XXI wieku, Wydawnictwo Krytyka Polityczna, Warszawa.

Piketty T., 2015b, About Capital in the Twenty-First Century, "American Economic Review", vol. 105, no. 5 . 
Raport placowy Sedlak \& Sedlak 2015, 2015, Sedlak \& Sedlak.

Rincon-Aznar A., Vecchi M., Venturini F., 2015, Inequalities During and After Transition in Central and Eastern Europe, [in:] Studies in Economic Transition. Functional Income Distribution in European Transition Countries, C. Perugini, F. Pompei (eds.), Palgrave, MacMillan UK.

Romer C. D., 1989, The Prewar Business Cycle Reconsidered: New Estimates of Gross National Product, 1869-1908, "Journal of Political Economy", no. 97.

Schneider D., 2011, The Labor Share: A Review of Theory and Evidence, SFB 649 Discussion Paper 2011-069, http://edoc.hu-berlin.de/series/sfb-649-papers/201169/PDF/ 69.pdf (data wejścia: 10.08.2016).

Serres A., Scarpetta S., Maisonneuve C., 2001, Falling Wage Shares in Europe and the United States: How Important is Aggregation Bias? "Empirica", no. 28.

Staniek Z., 2010, Zróżnicowanie ekonomii instytucjonalnej, http://jacek.kwasniewski.eu.org/ file/Staniek.pdf (data wejścia: 05.06.2012).

Stockhammer E., 2013, Why have wage shares fallen? A panel analysis of the determinants of functional income distribution, International Labour Office, Genewa.

The Labour Share in G20 Economies International Labour Organization. Organisation for Economic Co-operation and Development, 2015, OECD, https://www.oecd.org/g20/topics / employment-and-social-policy/The-Labour-Share-in-G20-Economies.pdf (data wejścia: 10.08.2016).

Trapp K., 2015, Measuring the labour income share of developing countries, WIDER Working Paper 041, https://www.wider.unu.edu/sites/default/ files/wp2015-041.pdf (data wejścia: 10.08.2016). 